\title{
Osteoblastic Changes During Non-Small Cell Lung Cancer (NSCLC) Treatment: How to Distinguish between Objective Response and Progressive Disease
}

Francesco Gelsomino ${ }^{1^{*}}$, Valentina Ambrosini ${ }^{2}$, Marcello Tiseo ${ }^{3}$, Francesca Sperandi ${ }^{1}$, Barbara Melotti ${ }^{1}$ and Andrea Ardizzoni ${ }^{1}$

${ }^{1}$ Department of Oncology, Policlinico S. Orsola-Malpighi, Bologna, Italy

${ }^{2}$ Department of Nuclear Medicine, Policlinico S.Orsola-Malpighi, Bologna, Italy

${ }^{3}$ Medical Oncology Unit, Azienda Ospedaliero-Universitaria, Parma, Italy

*Corresponding author: Francesco Gelsomino, Oncology Unit, Policlinico S.Orsola-Malpighi, Via Albertoni 15, 40138, Bologna, Italy, Tel: 0039 051 2142639; E-mail: francesco.gelsomino@tin.it

Received date: July 02, 2016; Accepted date: August 03, 2016; Published date: August 17, 2016

Copyright: ( 2016 Gelsomino F, et al. This is an open-access article distributed under the terms of the Creative Commons Attribution License, which permits unrestricted use, distribution, and reproduction in any medium, provided the original author and source are credited

\section{Short Communication}

Recently, we published an article reporting an example of the potential misinterpretation in the evaluation of osteoblastic changes during tyrosine-kinase inhibitor treatment in metastatic ALKrearranged non-small cell lung cancer (NSCLC) [1].

Bone metastases are common in disseminated NSCLC, occurring in approximately $30 \%$ to $40 \%$ of patients [2]. In the majority of cases, they present an osteolytic imaging pattern, even though osteoblastic or mixed-type patterns have also been reported in nearly $8 \%$ of cases $[3,4]$. Generally, in the assessment of objective response to anticancer agents, bone metastases are classified as non-target lesions and therefore "not evaluable" for response. However, according to the revised Response Evaluation Criteria in Solid Tumors guideline (RECIST version 1.1) [5], the appearance of new non-target lesions, including lytic or osteoblastic bone metastases, is a criterion for defining progressive disease. Sometimes, the evaluation of bone lesion response may be challenging and misinterpreted.

A caveat regarding the correct evaluation and interpretation of osteoblastic changes during treatment, usually referred to as "osteoblastic flare" or "osteoblastic reaction/response", has been raised. In our opinion, these two terms, however, refer to two completely different conditions which need to be clearly distinguished.
Osteoblastic flare is a more appropriate term to describe a transient tumor progression, as indicated by worsening of symptoms, circulating tumor or bone biomarkers and functional imaging techniques (such as positron emission tomography and bone scintigraphy), preluding to a subsequent improvement. This paradoxical phenomenon seems to be related to an increased osteoblastic activity as result of early mechanisms of repair around the bone lesion [6]. In the last years, positron emission tomography (18F-FDG PET/CT) has replaced bone scintigraphy for the detection of bone metastases due to its higher sensitivity (85\%) and specificity (99\%) and to the concurrent acquisition of low-dose-CT images that provide an anatomical and possible bone structural characterization of increased tracer uptake sites [7].

Furthermore, in presence of osteoblastic reaction, bone scintigraphy might be inadequate to assess response during anticancer treatments as it could persistently show osteoblastic activity, irrespective of tumor control [8]. In NSCLC, different case series on transient increased bone 18 F-FDG uptake during chemotherapy $[9,10]$ indicating initial response to anticancer treatment rather than a treatment failure, have been reported. Similar findings have also been described with $18 \mathrm{~F}$ FDG-PET/CT [11] and 99mTc-Bone Scintigraphy during EGFR TKIs (Table 1) $[12,13]$.

\begin{tabular}{|l|l|l|l|l|l|l|}
\hline & No. of pts (\%) & Histology & Therapy & $\begin{array}{l}\text { Best } \\
\text { response }\end{array}$ & $\begin{array}{l}\text { First evidence of BF } \\
\text { (weeks) }\end{array}$ & Imaging \\
\hline Lemieux et al. [10] & $2 / 33(6)$ & $\begin{array}{l}\text { LCC } \\
\text { ADC }\end{array}$ & CTX & $\begin{array}{l}\text { PR } \\
\text { PR }\end{array}$ & $\begin{array}{l}13 \\
6.3\end{array}$ & BS \\
\hline Chao et al. [13] & $7 / 33(21.2)$ & $\begin{array}{l}\text { ADC (5) } \\
\text { NSCLC NOS (2) }\end{array}$ & Gefitinib & PR & $4.8(4.1-11.0)$ & BS \\
\hline Krupitskay et al. [9] & 4 & ADC & Beva + CTX & $\begin{array}{l}\text { SD (2) } \\
\text { PR (2) }\end{array}$ & $6(6.0-9.0)$ & $\begin{array}{l}18 F-F D G- \\
\text { PET }\end{array}$ \\
\hline Hashisako et al. [12] & 1 & ADC & Gefitinib & PR & 4 & BS \\
\hline $\begin{array}{l}\text { LCC: large cell carcinoma; ADC: Adenocarcinoma; CTX: Chemotherapy; PR: Partial Response; BS: Bone Scintigraphy; NSCLC NOS: Non-Small Cell Lung Cancer } \\
\text { Not Otherwise Specified; Beva: Bevacizumab; SD: stable disease; 18F-FDG-PET/CT: 18 Fluorine-fluorodeoxyglucose-positron emission tomography }\end{array}$
\end{tabular}

Table 1: Studies on Bone Flare (BF) during any treatment in NSCLC.

On the contrary, osteoblastic reaction/response consists in the appearance of either new osteoblastic lesions or of a sclerotic component within or around lytic lesions at CT imaging. These radiological patterns, in the absence of other signs of progressive disease, should probably not be regarded as disease progression, but rather as healing of already established lytic metastases, as described in 
Citation: Gelsomino F, Ambrosini V, Tiseo M, Sperandi F, Melotti B, et al. (2016) Osteoblastic Changes During Non-Small Cell Lung Cancer (NSCLC) Treatment: How to Distinguish between Objective Response and Progressive Disease. J Nucl Med Radiat Ther 7: 296. doi: $10.4172 / 2155-9619.1000296$

Page 2 of 3

prostate [14], breast [15] and small cell lung cancer (SCLC) [16,17]. Osteoblastic reactions have also been reported during epidermal growth factor receptor (EGFR) tyrosine kinase inhibitor (TKI) treatment. In EGFR-addicted NSCLC population treated with targeted therapy, osteoblastic reaction reached prevalence higher than $20 \%$ [18]. Patients with osteosclerotic changes during EGFR TKI therapy showed good objective response both in primary and other metastatic sites $[18,19]$. Finally, these morphological changes after EGFR TKI could be significantly related to an improved survival $(p<0.01)$ (Table 2) [20]. In oncogene-addicted NSCLC, the different tumor response patterns of bone metastases during EGFR TKI therapy may be related either to a direct cytotoxic effect on tumor cells or to an indirect effect on bone lesions by acting on bone tumor niche and its microenvironment, through anti-angiogenic mechanisms and the inhibition of osteoclasts recruitment [21].

\begin{tabular}{|l|l|l|l|l|l|l|}
\hline Author & No. of pts (\%) & Histology & Therapy & Best Response & $\begin{array}{l}\text { First evidence of OR } \\
\text { (weeks) }\end{array}$ & Imaging \\
\hline Bersanelli et al. [18] & $10 / 43(23)$ & $\begin{array}{l}\text { ADC (39) } \\
\text { Others (4) }\end{array}$ & $\begin{array}{l}\text { Erlotinib (12) } \\
\text { Gefitinib (5) }\end{array}$ & $\begin{array}{l}\text { PR (7) } \\
\text { SD (2) } \\
\text { PD (1) }\end{array}$ & $4.3-17.4$ \\
\hline Pluquet et al. [19] & $17 / 36(36)$ & $\begin{array}{l}\text { ADC (32) } \\
\text { Others (4) }\end{array}$ & $\begin{array}{l}\text { Erlotinib (12) } \\
\text { Gefitinib (5) }\end{array}$ & $\begin{array}{l}\text { PR/SD (12) } \\
\text { PD (5) }\end{array}$ & NR \\
\hline Yamashita et al. [20] & $11 / 41(27)$ & ADC & Gefitinib & PR & $9(3.0-28.4)$ & CT \\
\hline Lind et al. [22] & 3 & ADC & Erlotinib & PR & $10(6-13.04)$ & CT \\
\hline Ansén et al. [23] & 3 & ADC & Erlotinib (2) & Pefitinib (1) & $8(7-13.04)$ & CT \\
\hline
\end{tabular}

Table 2: Studies on osteoblastic reaction (or) during EGFR-TKI treatment in NSCLC.

In our opinion this phenomenon represents an underestimated condition of bone metastases response, particularly in highly chemosensitive tumors and in oncogene-addicted ones. In clinical practice, a misinterpretation of these morphological or functional bone changes could lead to erroneously discontinue an effective treatment and finally have a negative impact on patients' clinical outcome. To avoid this mistake, we believe that both a correct evaluation of patients' clinical condition and computed tomography imaging is crucial. In presence of a clinical benefit and tumor response in extra-skeletal sites, an apparent worsening of bone imaging at standard CT scan should not lead to modify the current treatment strategy. In these circumstances, integrating $18 \mathrm{~F}-\mathrm{FDG}-\mathrm{PET} / \mathrm{CT}$ with standard imaging could improve the evaluation of bone metastatic disease and help in distinguishing bone flare from bone reaction/response and bone progressive disease.

\section{Acknowledgement}

This work was supported by Associazione Italiana per la Ricerca sul Cancro (AIRC), Milan grant IG 14214

\section{References}

1. Gelsomino F, Ambrosini V, Melotti B, Sperandi F, Ardizzoni A (2016) Pitfalls in oncology: osteoblastic response mimicking bone progression during ceritinib treatment in ALK-rearranged non-small cell lung cancer (NSCLC). J Thorac Oncol 11: e99-e101.

2. Coleman RE (2006) Clinical features of metastatic bone disease and risk of skeletal morbidity. Clin Cancer Res 12: 6243s-6249s.

3. Koizumi M (2004) Bone metastasis. The Bone 18: 583-586

4. Napoli LD, Hansen HH, Muggia FM, Twigg HL (1973) The incidence of osseous involvement in lung cancer, with special reference to the development of osteoblastic changes. Radiology 108: 17-21.
5. Eisenhauer EA, Therasse P, Bogaerts J, Schwartz LH, Sargent D, et al. (2009) New response evaluation criteria in solid tumors: revised RECIST guideline (version 1.1). Eur J Cancer 45: 228-247.

6. Coleman RE, Mashiter G, Whitaker KB, Moss DW, Rubens RD, et al. (1988) Bone scan flare predicts successful systemic therapy for bone metastases. J Nucl Med 29: 1354-1359.

7. Cook GJ, Fogelman I (2000) The role of positron emission tomography in the management of bone metastases. Cancer 88: 2927-2933.

8. Al-Muqbel KM, Yaghan RJ (2016) Effectiveness of 18F-FDG-PET/CT vs bone scintigraphy in treatment response assessment of bone metastases in breast cancer. Medicine (Baltimore) 95: e3753.

9. Krupitskaya Y, Eslamy HK, Nguyen DD, Kumar A, Wakelee HA (2009) Osteoblastic bone flare on F18-FDG PET in non-small cell lung cancer (NSCLC) patients receiving Bevacizumab in addition to standard chemotherapy. J Thorac Oncol 4: 429-431.

10. Lemieux J, Guimond J, Laberge F, St-Pierre C, Cormier Y (2002) The bone scan flare phenomenon in non-small-cell lung cancer. Clin Nucl Med 27: 486-489.

11. Al-Nabhani K, Syed R, Haroon A, Almukhailed O, Bomanji J (2012) Flare response versus disease progression in patients with non-small cell lung cancer. J Radiol Case Rep 6: 34-42.

12. Hashisako M, Wakamatsu K, Ikegame S, Kumazoe H, Nagata N, et al. (2012) Flare phenomenon following gefitinib treatment of lung adenocarcinoma with bone metastasis. Tohoku J Exp Med 228: 163-168.

13. Chao HS, Chang CP, Chiu CH, Chu LS, Chen YM, et al. (2009) Bone scan flare phenomenon in non-small-cell lung cancer patients treated with gefitinib. Clin Nucl Med 34: 346-349.

14. Messiou C, Cook G, Reid AH, Attard G, Dearnaley D, et al. (2011) The CT flare response of metastatic bone disease in prostate cancer. Acta Radiol 52: 557-561.

15. Schneider JA, Divgi CR, Scott AM, Macapinlac HA, Seidman AD, et al. (1994) Flare on bone scintigraphy following Taxol chemotherapy for metastatic breast cancer. J Nucl Med 35: 1748-1752. 
Citation: Gelsomino F, Ambrosini V, Tiseo M, Sperandi F, Melotti B, et al. (2016) Osteoblastic Changes During Non-Small Cell Lung Cancer (NSCLC) Treatment: How to Distinguish between Objective Response and Progressive Disease. J Nucl Med Radiat Ther 7: 296. doi: $10.4172 / 2155-9619.1000296$

Page 3 of 3

16. Fink C, Hasan B, Deleu S, Pallis AG, Baas P, et al. (2012) High prevalence of osteoblastic bone reaction in computed tomography scans of an European Organisation for research and Treatment of cancer prospective randomised phase II trial in extensive stage small cell lung cancer. Eur J Cancer 48: 3157-3160.

17. Stattaus J, Hahn S, Gauler T, Eberhardt W, Mueller SP, et al. (2009) Osteoblastic response as a healing reaction to chemotherapy mimicking progressive disease in patients with small cell lung cancer. Eur Radiol 19 193-200.

18. Bersanelli M, Bini P, Rabaiotti E, Facchinetti F, De Filippo M, et al. (2015) Osteoblastic progression during EGFR tyrosine kinase inhibitor therapy in mutated non-small cell lung cancer: a potential blunder. Tumori 19.

19. Pluquet E, Cadranel J, Legendre A, Faller MB, Souquet PJ, et al. (2010) Osteoblastic reaction in non-small cell lung carcinoma and its association to epidermal growth factor receptor tyrosine kinase inhibitors response and prolonged survival. J Thorac Oncol 5: 491-496.
20. Yamashita Y, Aoki T, Hanagiri T, Yoshii C, Mukae H, et al. (2012) Osteosclerotic lesions in patients treated with gefitinib for lung adenocarcinomas: a sign of favorable therapeutic response. Skeletal Radiol 41: 409-414.

21. Normanno N, De Luca A, Aldinucci D, Maiello MR, Mancino M, et al. (2005) Gefitinib inhibits the ability of human bone marrow stromal cells to induce osteoclast differentiation: implications for the pathogenesis and treatment of bone metastasis. Endocr Relat Cancer 12: 471-482.

22. Lind JS, Postmus PE, Smit EF (2010) Osteoblastic bone lesions developing during treatment with erlotinib indicate major response in patients with non-small cell lung cancer: a brief report. J Thorac Oncol 5: 554-557.

23. Ansén S, Bangard C, Querings S, Gabler F, Scheffler M, et al. (2010) Osteoblastic response in patients with non-small cell lung cancer with activating EGFR mutations and bone mestastases during treatment with EGFR kinase inhibitors. J Thorac Oncol 5: 407-409. 